\title{
Technical Efficiency of Vietnamese Commercial Banks
}

\author{
Linh Trinh Doan Tuan \\ University of Economisc anh Law, Viet Nam National University, Hochiminh City, Vietnam
}

\section{Email address:}

linhtdt1410101@sdh.uel.edu.vn

\section{To cite this article:}

Linh Trinh Doan Tuan. Technical Efficiency of Vietnamese Commercial Banks. American Journal of Theoretical and Applied Business. Vol. 6, No. 2, 2020, pp. 17-22. doi: 10.11648/j.ajtab.20200602.12

Received: August 7, 2020; Accepted: August 22, 2020; Published: August 31, 2020

\begin{abstract}
The objective of this study is to analyze the technical efficiency of commercial banks operating in Vietnam, with an analysis of 30 out of 44 existing commercial banks. The author uses a parametric method with a Stochastic Frontier Analysis (SFA) with independent variables including equity, customer deposits, loans and total operating costs, and the dependent variable is total operating income. The results show that the mean technical efficiency of Vietnamese commercial banks in the research period is 0.728 , the lowest efficiency is 0.692 , the highest efficiency is 0.761 . The technical efficiency of Vietnamese commercial banks in this period is low, the reason for the low efficiency of Vietnamese banks is that during this period, the Vietnamese banking system has just gone through a difficult period 2008 - 2012 and the Government of Vietnam restructured the banking system and credit institutions. Among commercial banks that are operating in weak cases, they are forced to restructure by mergers, acquisitions... this affects the overall average efficiency of the entire Vietnamese commercial banking system. The research results also show that the group of foreign banks has the highest average technical efficiency, with an average efficiency of 0.85 . The group of state-owned commercial banks with average efficiency ranked second, this group having an average technical efficiency of 0.76 . The group of private banks with the lowest average efficiency, this group has an average efficiency of 0.71 . Foreign banks in Vietnam are subsidiary banks owned by major banking groups in the world such as HSBC, Shinhanbank, Standard Chartered.... These banks have advantages in capital, experience, and energy. governance, banking technology advantages... should have the highest operational efficiency. State-owned banks have a longer history of development than private banks, have capital from the state and have incentives from the government... so they are more effective than private banks in Viet Nam.
\end{abstract}

Keywords: SFA, Technical Efficiency, Commercial Bank

\section{Introduction}

There are currently 44 active commercial banks in Vietnam, including four state-owned commercial banks, 31 private commercial banks and 9 foreign banks. In recent years, the number of non-bank financial institutions and foreign commercial banks has increased, from the number of 5 banks in 2015 , by the end of 2019 there were 9 foreign banks in Vietnam, from The number of 10 financial companies operating in Vietnam by 2025 has now increased to 16 financial companies. This shows that in the current competitive and integrated environment, the Vietnamese banking system must not only maintain its operational efficiency and must improve its competitiveness with non-bank financial institutions, especially is competing with foreign banks that are entering Vietnam market to compete for market share.
Due to the importance of improving the performance of Vietnamese commercial banks in the process of international integration, many authors have been interested in research over the past years. However, these studies mainly approach traditional qualitative analysis methods such as: research by $[1,2]$, These studies are qualitative analysis and the scope of the study focused only on the group of state-owned commercial banks. Quantitative research on measuring the performance of commercial banks in general in the country is still small, although recently there are studies by [3-5], evaluated the effectiveness of commercial banks based on a quantitative approach using the two popular methods, SFA and DEA, but limited the version of the study is an old research context or is it only researched for some Vietnamese commercial banks.

The question is the technical efficiency of Vietnamese commercial banks in the current context, what factors affect 
the technical efficiency of Vietnamese commercial banks. To answer those questions, the goal of this study is to estimate the technical efficiency by taking a parameter approach with the Stochastic Frontier Analysis (SFA) method and identifying the factors that affect technical efficiency. The technical implications of Vietnamese commercial banks in the period of 2013 - 2019, from which the recommendations imply the policy of improving the technical efficiency of Vietnamese commercial banks.

\section{Technical Efficiency of Commercial Banks}

There are two methods to assess the technical efficiency of banks: non-parametric method and parametric method. Studies using such non-parametric method include: [6], using data analysis method (DEA) to estimate the effectiveness of 201 major US banks. The article by $\mathrm{M}$. Ismail studied the effectiveness of Malaysia's commercial banking system in the period of 1994-2000 using the data envelope method [7, 8] uses DEA to estimate the technical efficiency for major banking markets of 15 European countries. [9] uses DEA to study the performance of 26 banks including domestic banks and foreign banks operating in South Africa. Or the study of [10] uses data enveloping method (DEA) to measure the technical efficiency of banks in countries of Vietnam, Thailand, Malaysia, Philippines, Indonesia 1998 - 2004. [11] use the DEA approach to estimate the effectiveness of the Indian banking system.

In recent years, there have been many studies in many countries and territories studying the efficiency of banking industry. [12] uses DEA to estimate technical efficiency (TE), scale efficiency (SE), cost effectiveness (CE), mixed efficiency (ME) of commercial banks in 4 ASEAN countries. [13] uses DEA method to estimate the effectiveness of the system of 217 commercial banks in 10 countries MENA. [14] investigated the efficiency of the Mexican commercial banking system from 2002 to 2012 by using DEA approach.

Studies using SFA methods in the world include: [15] used the Stochastic Frontier Analysis (SFA) to evaluate the performance of commercial banks in four countries including Thailand, Indonesia, Malaysia and Philippines. [16] used the Stochastic Frontier Analysis (SFA) to study the X efficiency of China's commercial banking system.

The effectiveness studies of Vietnamese commercial banks include: [3] used the DEA and SFA approach to evaluate the performance of Vietnamese commercial banks through a sample of 32 commercial banks in 2001-2005. [4] analyzed the effectiveness of 22 Vietnamese commercial banks in 2008 using the DEA data envelope analysis method. [5] with the approach Data envelope analysis (DEA) and stochastic boundary analysis (SFA evaluate the effectiveness of Vietnamese commercial banks in the period of 2000-2007 and 2008-2012.

In previous studies on the effectiveness of the bank largely used the DEA method. However, the limitation of DEA method is that it cannot assess the impact of the inputs on the outputs, so in this study, the author uses parametric method with SFA methods to assess the technical efficiency of Vietnamese banks and the influence of factors on the technical efficiency of banks.

\section{SFA Approach}

The technical efficiency of commercial banks can be estimated using both parametric and nonparametric methods. In this study, the author estimates the technical efficiency according to the parametric approach by Stochastic Frontier Analysis (SFA).

The SFA method is commonly used in analysis models of production function, cost function or profit function. In this study uses the Stochastic Frontier Production Function was proposed by $[17,18]$ ) and developed by [19].

The Frontier production function has the form:

$$
\mathrm{Y}_{\mathrm{i}}=f\left(\mathrm{x}_{\mathrm{ij}} ; \beta\right) \exp \left(\mathrm{V}_{\mathrm{i}}-\mathrm{U}_{\mathrm{i}}\right)
$$

Where:

$\mathrm{Yi}$ is the total operating income of the bank $\mathrm{i}$

$\mathrm{Xij}$ is the j-th element of the ith bank

$\beta$ is the coefficient to be estimated (parameter of the variable $\mathrm{Xij}$ )

$V_{i}$ is a statistical error due to random factors and is assumed to have a normal distribution (iid), $\mathrm{N}\left(0, \sigma \mathrm{v}^{2}\right)$ and is independent of $U_{i}$.

$\mathrm{Ui}$ is the technically ineffective part, which is assumed to be greater than or equal to 0 and has a half-normal distribution $\mathrm{N}\left(0, \delta \mathrm{u}^{2}\right)$. If $\mathrm{U}=0$ activities of banks on the boundary, the effectiveness of banks will be maximized based on existing factors and techniques. If $U>0$ operation of banks is below the boundary, the actual efficiency (Yi) is lower than the maximum efficiency $\left(\mathrm{Y}^{*}\right)$ and the difference $\left(\mathrm{Y}^{*}-\mathrm{Yi}\right)$ is the non-technical efficiency part. The higher the coefficient is, the lower the technical efficiency and vice versa (Coelli et al.., 2005).

The technical efficiency (TE) is calculated as follows:

$$
\mathrm{TE}=\mathrm{Yi} / \mathrm{Yi}^{*}=f\left(\mathrm{x}_{\mathrm{ij}} ; \beta\right) \operatorname{xp}\left(\mathrm{V}_{\mathrm{i}}-\mathrm{U}_{\mathrm{i}}\right) / f\left(\mathrm{x}_{\mathrm{ij}} ; \beta\right) \exp \left(\mathrm{V}_{\mathrm{i}}\right)=\exp (-\mathrm{Ui})
$$

In which $\mathrm{Yi} ; \mathrm{Yi} *$ is the total actual income and the maximum income of the $\mathrm{i}$ bank; ij (xij; $\beta$ ) is a frontier production function. The estimates in the paper were calculated using FRONTIER 4.1 software. The coefficients were estimated using the maximum likelihood method through three steps:

(1) The first OLS regression is performed, the coefficients $\beta$ except the blocking coefficients are non-biased estimates.

(2) Use grid search to estimate $\gamma$

(3) The result obtained from step 2 is used as the initial value of the iterative algorithm according to the Davidon Fletcher - Powell Quasi - Newton method to obtain maximum likelihood estimates.

Then the technical inefficiencies of each firm in each period will be calculated according to the formula of [20] The 
estimate of the average inefficiencies of each period is only the algebraic average of the individual values for each bank.

In the SFA method, we need to estimate a production function, the production function can be estimated by many different models such as Leontief function, linear production function, homogeneous production function, production function CES format, neoclassical function, Cobb - Douglas function, translog function. In manufacturing economics there are two commonly used models: Cobb - Douglas production function and translog production function, we need to test which function format is more suitable for research model.

The Cobb - Douglas function:

$$
\operatorname{Ln} Y i=\beta_{0}+\beta_{1} \ln X_{1} \mathrm{i}+\beta_{2} \ln X_{2} i+\beta_{3} \ln X_{3} i+\beta_{4} \ln X_{4} i+(V i-U i)
$$

Translog function:

$$
\operatorname{LnYi}=\beta_{0}+\sum_{j=1}^{4} \beta_{j} \ln X_{j i}+\frac{1}{2} \sum_{j=1}^{4} \sum_{k=1}^{4} \cdot \beta_{j k} \ln X_{j i} \ln X_{k i}+(V i-U i)
$$

Where $\mathrm{Yi}$ is the total income of the $\mathrm{i}$-th bank $(\mathrm{i}=1,2 . .5), \mathrm{Xji}$ is the $\mathrm{j}$-th inputs of the $\mathrm{i}$-th bank $(\mathrm{j}=1,2,3,4)$.

The LR test is used to select the Cobb - Douglas estimation model (formula 3) or Translog (formula 4) based on the values of $\lambda=-2$ [L (H0) - L (H1)]. Where L (H0) is the log - likelihood value of the Cobb - Douglas model, L (H1) is the log likelihood value of the Translog model. If $\lambda<$ value of looking up table, Cobb - Douglas model is selected, otherwise Translog model is selected. The value of looking up the table is taken from table $\mathrm{x}^{2}$ with the free turn (df) equal to the parameter number of $\lambda$ Translog model minus the parameter number of Cobb - Douglas model. Calculation results show that $\lambda=-2$ $[(87.96)-(70.89)]=-34.14$ lookup table value abletable $\left(\mathrm{x}^{2}\right.$, $\mathrm{df}=10)=30.58$. Cobb - Douglas model selected.

\section{Data}

The total sample of the study is 30 commercial banks out of a total of 44 commercial banks operating in Vietnam, including 2 foreign commercial banks, 4 state-owned commercial banks and 24 private commercial banks. State banks include the state-owned commercial banks, private banks are joint-stock commercial banks owned by individuals and organizations outside the state, foreign banks are commercial banks established with $100 \%$ capital. established by foreign banks in Vietnam.

Data sources are taken from annual reports, financial statements of Vietnamese commercial banks in the period of 2013-2019, and data of the State Bank of Vietnam.

The variables of the model include 4 independent variables: Equity (X1 - EQT), Deposits from customers (X2 DEP), loans (deposits and borrowings from other credit institutions, loans from the State Bank, and paper issuance). valuable papers, debt securities, other loans) (X3 - BOR) and operating expenses (X4 - OPE). The dependent variable is the total operating income (Y - TOI). The inputs and outputs are shown in tables 1 and 2 .

Table 1. Summary of Descriptive Statistics.

\begin{tabular}{lllll}
\hline Variables & Obs & Mean & Std. Dev & Min \\
\hline Y - Total operating income & 210 & $7,820,778$ & $1.08 \mathrm{e}+07$ & 449,555 \\
X1 - Equity & 210 & $15,593,882$ & $1.67 \mathrm{e}+07$ & $1,228,606$ \\
X2 - Deposits & 210 & $171,761,012$ & $2.40 \mathrm{e}+08$ & $8,602,306$ \\
X3 - Loans & 210 & $40,638,942$ & $5.44 \mathrm{e}+07$ & $79,295,114$ \\
X4 - Operating expenses & 210 & $3,575,858$ & $4,479,873$ & 20,117 \\
\hline
\end{tabular}

Table 2. Bank inputs and outputs in Vietnam 2013-2019.

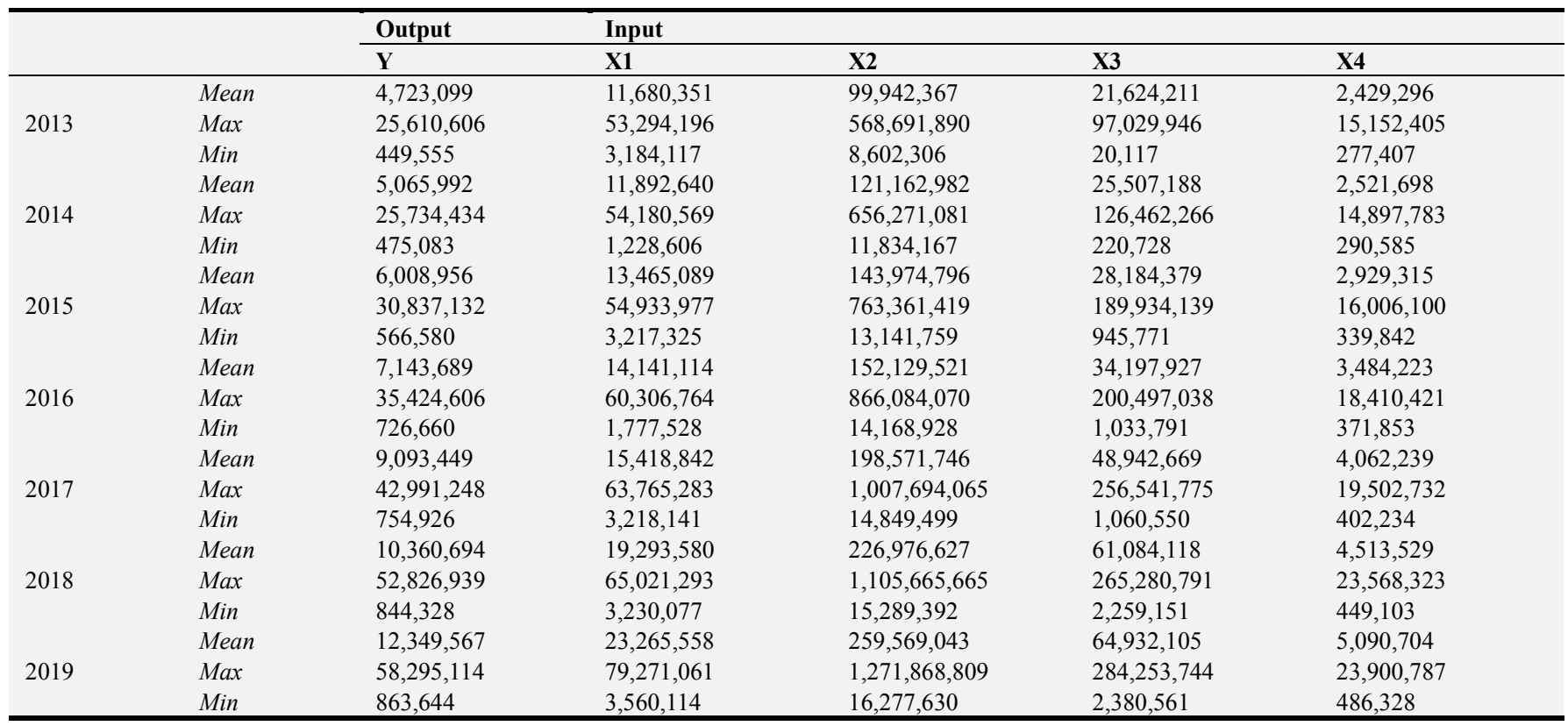




\begin{tabular}{llllll}
\hline & Output & Input & & & \\
\cline { 2 - 6 } & Y & X1 & X2 & X3 & X4 \\
\hline Mean & $7,820,778$ & $15,593,882$ & $171,761,012$ & $40,638,942$ & $3,575,858$ \\
Max & $58,295,114$ & $79,271,061$ & $1,271,868,809$ & $284,253,744$ & $23,900,787$ \\
Min & 449,555 & $1,228,606$ & $8,602,306$ & 20,117 & 277,407 \\
\hline
\end{tabular}

\section{Results and Discussion}

The estimation results by MLE method in Table 3 show that, among the input factors, operating cost (EQT - $\beta 4)$ is the component with the strongest impact on total income of banks in the period. In addition, equity also has a great impact on the income and performance of banks. This is consistent with the fact that large commercial banks are often more efficient. On the other hand, large equity means that banks can increase their total assets, which is consistent with the results of the analysis of operational efficiency, most of the banks with high operating efficiency are among largescale commercial banks. In addition, customer deposits and loans are closely related to the bank's total operating income. Controlling costs, limiting loans, maintaining a reasonable balance of customer deposits will help banks maintain and increase income and operational efficiency.

Table 3. Model estimation results.

\begin{tabular}{llll}
\hline & coefficient & standard-error & t-ratio \\
\hline EQT $\left(\beta_{1}\right)$ & $0.13409282 \mathrm{E}+00$ & $0.31419149 \mathrm{E}-01$ & $0.42678691 \mathrm{E}+01$ \\
DEP $\left(\beta_{2}\right)$ & $0.21525844 \mathrm{E}-01$ & $0.41157250 \mathrm{E}-01$ & $0.52301463 \mathrm{E}+00$ \\
BOR $\left(\beta_{3}\right)$ & $-0.13256445 \mathrm{E}-01$ & $0.17673450 \mathrm{E}-01$ & $-0.75007678 \mathrm{E}+00$ \\
OPE $\left(\beta_{4}\right)$ & $0.96018279 \mathrm{E}+00$ & $0.54659397 \mathrm{E}-01$ & $0.17566655 \mathrm{E}+02$ \\
Constant $\left(\beta_{0}\right)$ & $-0.77872516 \mathrm{E}+00$ & $0.50340474 \mathrm{E}+00$ & $-0.15469166 \mathrm{E}+01$ \\
sigma-squared & $0.36778413 \mathrm{E}-01$ & $0.96722814 \mathrm{E}-02$ & $0.38024548 \mathrm{E}+01$ \\
gamma $(\gamma)$ & $0.50388482 \mathrm{E}+00$ & $0.11250277 \mathrm{E}+00$ & $0.44788658 \mathrm{E}+01$ \\
mu $(\mu)$ & $0.27226519 \mathrm{E}+00$ & $0.79458692 \mathrm{E}-01$ & $0.34264998 \mathrm{E}+01$ \\
Eta $(\eta)$ & $0.51343804 \mathrm{E}-01$ & $0.18286165 \mathrm{E}-01$ & $0.28077951 \mathrm{E}+01$ \\
log likelihood function & & $0.87958239 \mathrm{E}+02$ & \\
LR & & $0.99317992 \mathrm{E}+02$ & \\
Observations: 210 & & & \\
\hline
\end{tabular}

The result of the coefficient $\gamma$ in the model is $0.5 \# 0$, representing the inefficiency component of the model's error, which shows that it is necessary to include a random component in the estimation model and reliable. The coefficient $\eta$ indicates the efficiency change over time, the estimated results $\eta=0.051$ show that the efficiency of banks tends to increase in the research period.

Efficiency of banks by SFA method according to [20] process, after estimating the random margin production function in the above step, using Frontier 4.1 software, the technical efficiency of banks is presented. In Table 4, the results show that the average efficiency of the entire system during the study period is 0.728 , the lowest efficiency is 0.43 , the highest efficiency is 0.94 . This result also shows that the efficiency of Vietnam's commercial banks in the period 2013 - 2019 is relatively low, with this result if the output average does not change, commercial banks can save money. $27 \%$ maximum of input.

Table 4. Technical efficiency of Vietnamese commercial banks in the period of 2013-2019.

\begin{tabular}{|c|c|c|c|c|c|c|c|c|}
\hline & Banks & 2013 & 2014 & 2015 & 2016 & 2017 & 2018 & 2019 \\
\hline 1 & ACB & 0.608 & 0.623 & 0.638 & 0.652 & 0.666 & 0.680 & 0.693 \\
\hline 2 & AGB & 0.607 & 0.623 & 0.638 & 0.652 & 0.666 & 0.680 & 0.693 \\
\hline 3 & $\mathrm{ABB}$ & 0.629 & 0.644 & 0.658 & 0.672 & 0.686 & 0.699 & 0.711 \\
\hline 4 & $\mathrm{BAB}$ & 0.794 & 0.803 & 0.812 & 0.820 & 0.828 & 0.836 & 0.844 \\
\hline 5 & BVB & 0.729 & 0.740 & 0.751 & 0.762 & 0.772 & 0.782 & 0.792 \\
\hline 6 & BIDV & 0.836 & 0.843 & 0.851 & 0.858 & 0.864 & 0.870 & 0.876 \\
\hline 7 & EIB & 0.552 & 0.569 & 0.585 & 0.601 & 0.616 & 0.631 & 0.646 \\
\hline 9 & HSC & 0.729 & 0.741 & 0.752 & 0.763 & 0.773 & 0.783 & 0.793 \\
\hline 10 & KLB & 0.581 & 0.597 & 0.613 & 0.628 & 0.643 & 0.657 & 0.671 \\
\hline 11 & LVB & 0.619 & 0.634 & 0.648 & 0.663 & 0.676 & 0.690 & 0.703 \\
\hline 12 & MSB & 0.577 & 0.593 & 0.608 & 0.624 & 0.638 & 0.653 & 0.667 \\
\hline 13 & MBB & 0.867 & 0.873 & 0.879 & 0.885 & 0.890 & 0.895 & 0.900 \\
\hline 14 & NAB & 0.678 & 0.691 & 0.704 & 0.717 & 0.729 & 0.740 & 0.751 \\
\hline 15 & NCB & 0.483 & 0.501 & 0.518 & 0.535 & 0.552 & 0.569 & 0.585 \\
\hline 18 & STB & 0.495 & 0.513 & 0.530 & 0.547 & 0.564 & 0.580 & 0.596 \\
\hline 19 & SGB & 0.755 & 0.766 & 0.776 & 0.786 & 0.795 & 0.804 & 0.813 \\
\hline
\end{tabular}




\begin{tabular}{|c|c|c|c|c|c|c|c|c|}
\hline & Banks & 2013 & 2014 & 2015 & 2016 & 2017 & 2018 & 2019 \\
\hline 20 & SCB & 0.545 & 0.562 & 0.578 & 0.594 & 0.610 & 0.625 & 0.640 \\
\hline 21 & SEA & 0.603 & 0.618 & 0.633 & 0.648 & 0.662 & 0.676 & 0.689 \\
\hline 22 & SHB & 0.680 & 0.693 & 0.706 & 0.718 & 0.730 & 0.741 & 0.753 \\
\hline 23 & SHI & 0.920 & 0.924 & 0.927 & 0.931 & 0.934 & 0.937 & 0.940 \\
\hline 24 & TCB & 0.838 & 0.846 & 0.853 & 0.860 & 0.866 & 0.872 & 0.878 \\
\hline 25 & ТPB & 0.765 & 0.775 & 0.785 & 0.794 & 0.803 & 0.812 & 0.821 \\
\hline 26 & VIB & 0.703 & 0.716 & 0.728 & 0.739 & 0.751 & 0.761 & 0.772 \\
\hline 28 & VCB & 0.794 & 0.803 & 0.812 & 0.820 & 0.829 & 0.836 & 0.844 \\
\hline 29 & CTG & 0.661 & 0.675 & 0.688 & 0.701 & 0.713 & 0.726 & 0.737 \\
\hline 30 & VPB & 0.855 & 0.861 & 0.868 & 0.874 & 0.880 & 0.885 & 0.891 \\
\hline Mean & & 0.692 & 0.705 & 0.717 & 0.728 & 0.740 & 0.750 & 0.761 \\
\hline $\operatorname{Max}$ & & 0.920 & 0.924 & 0.927 & 0.931 & 0.934 & 0.937 & 0.940 \\
\hline Min & & 0.483 & 0.501 & 0.535 & 0.552 & 0.552 & 0.569 & 0.585 \\
\hline
\end{tabular}

From the table of technical efficiency of banks (Table 4) shows that the technical efficiency of banks increases year by year in the average, largest and smallest. Most banks also show that most of the efficiency has improved year by year, although the rate is not large and breakthrough, this shows that the process of restructuring the commercial banking system of Vietnam is gradually taking effect. fruit.

Table 5. Descriptive statistics of Vietnamese banks' technical efficiency.

\begin{tabular}{|c|c|c|c|c|c|c|c|}
\hline \multirow{2}{*}{ TE } & \multicolumn{7}{|c|}{ Number of banks } \\
\hline & 2013 & 2014 & 2015 & 2016 & 2017 & 2018 & 2019 \\
\hline $0.9-1.0$ & 1 & 1 & 1 & 1 & 1 & 1 & 2 \\
\hline $0.8-<0.9$ & 4 & 7 & 7 & 7 & 7 & 9 & 8 \\
\hline $0.7-<0.8$ & 9 & 6 & 10 & 11 & 11 & 9 & 11 \\
\hline $0.6-<0.7$ & 10 & 10 & 8 & 8 & 9 & 9 & 7 \\
\hline $0.5-<0.6$ & 4 & 6 & 4 & 3 & 2 & 2 & 2 \\
\hline$<0.5$ & 2 & 0 & 0 & 0 & 0 & 0 & 0 \\
\hline Total & 30 & 30 & 30 & 30 & 30 & 30 & 30 \\
\hline Mean & 0.692 & 0.705 & 0.717 & 0.728 & 0.740 & 0.750 & 0.761 \\
\hline $\operatorname{Max}$ & 0.920 & 0.924 & 0.927 & 0.931 & 0.934 & 0.937 & 0.940 \\
\hline Min & 0.483 & 0.501 & 0.535 & 0.552 & 0.552 & 0.569 & 0.585 \\
\hline
\end{tabular}

During the research period, the group of highly efficient banks has been stable over the years, the data in Table 5 shows that in 6 years, there is 1 commercial bank with technical efficiency from 0.9 or more is Shinhanbank (SHI), which is the foreign bank, in 2019, there is one more bank in the effective level from 0.9, MBBank (MBB). The group of banks with 0.8 or more efficiency had 4 commercial banks in 2013 and increased to 7 commercial banks in 2014, this number was stable for 4 years and then increased to 9 banks in 2018 and 8 banks in 2019. Effective group from In 0.7 2014, there were 6 banks, in the remaining years the number of banks was between 9,10 and 11. Commercial banks in the group with technical efficiency below 0.6 decreased gradually over the years, this shows that many weak commercial banks have Successfully restructured and improved its operational efficiency.

The research results are presented in Table 6 showing that in the study period, the group of foreign banks with the highest average efficiency was 0.846 , followed by the group of state owned banks with average efficiency. With an average of 0.757 and lower ranked as a group of private banks with an average efficiency of 0.713 , and from 2013 to 2019 this position has not changed, foreign banks always lead in the efficiency level. ranked second is still the group of state-owned banks, the group of joint stock commercial banks ranked last in terms of efficiency in various types of commercial banks in Vietnam. The foreign banks in Vietnam in the sample have 2 commercial banks with $100 \%$ foreign capital, which are subsidiary banks of leading financial groups in the world and the continent, these commercial banks have advantages in capital and technology, experience, people... should be most effective. The group of state-owned banks has the oldest development process, has advantages in size and many priorities from the government... so their efficiency is higher than the group of joint stock commercial banks. In the research period, other than some commercial banks with high scale and efficiency such as ACB, MBBank, Techcombank, VPBank... there are still many small-sized commercial banks and some weak commercial banks in the restructuring area. leading to low average efficiency.

Table 6. Descriptive statistics of technical efficiency by ownership type.

\begin{tabular}{|c|c|c|c|c|c|c|c|c|c|}
\hline Ownership & & Period & 2013 & 2014 & 2015 & 2016 & 2017 & 2018 & 2019 \\
\hline \multirow{3}{*}{ State Banks } & Mean & 0.757 & 0.725 & 0.736 & 0.747 & 0.758 & 0.768 & 0.778 & 0.788 \\
\hline & $\operatorname{Max}$ & 0.876 & 0.836 & 0.843 & 0.851 & 0.858 & 0.864 & 0.870 & 0.876 \\
\hline & Min & 0.607 & 0.607 & 0.623 & 0.638 & 0.652 & 0.666 & 0.680 & 0.693 \\
\hline \multirow{2}{*}{ Private Banks } & Mean & 0.713 & 0.676 & 0.689 & 0.701 & 0.713 & 0.725 & 0.737 & 0.748 \\
\hline & $\operatorname{Max}$ & 0.900 & 0.867 & 0.873 & 0.879 & 0.885 & 0.890 & 0.895 & 0.900 \\
\hline
\end{tabular}




\begin{tabular}{|c|c|c|c|c|c|c|c|c|c|}
\hline Ownership & & Period & 2013 & 2014 & 2015 & 2016 & 2017 & 2018 & 2019 \\
\hline \multirow{4}{*}{ Foreign Banks } & Min & 0.483 & 0.483 & 0.501 & 0.518 & 0.535 & 0.552 & 0.569 & 0.585 \\
\hline & Mean & 0.846 & 0.824 & 0.832 & 0.840 & 0.847 & 0.853 & 0.860 & 0.866 \\
\hline & $\operatorname{Max}$ & 0.937 & 0.920 & 0.924 & 0.927 & 0.931 & 0.934 & 0.937 & 0.940 \\
\hline & Min & 0.729 & 0.729 & 0.741 & 0.752 & 0.763 & 0.773 & 0.783 & 0.793 \\
\hline
\end{tabular}

\section{Conclusions}

The study using SFA method to estimate the production function and technical efficiency according to the process of Battese and [20] with the help of Frontier 4.1 software. The results show that the average technical efficiency of the whole system in the study period is 0.728 , the lowest efficiency is 0.692 , the highest efficiency is 0.761 . The group of banks with technical efficiency from 0.9 and above is very few, only $1 / 30$. This result shows that commercial banks have not entered the sustainable development trajectory after the period of global economic crisis and restructuring the financial and banking system of the Government. The study also found that among the input factors, operating costs and equity have the strongest impact on the total income of commercial banks in Vietnam.

From the above results, in order to increase the operational efficiency in the banking system in the coming time, banks need to strengthen and gradually develop the scale and develop a reasonable cost management policy to increase. performance efficiency. At the same time, the determination of customers' loans and deposits at a more effective level not only ensures safety in operation but also contributes to safety for the whole system. Furthermore, banks should actively attract and cooperate with international capital sources to increase their working capital potentials, meeting the liquidity needs of the economy.

\section{References}

[1] L. T. Huong, Improve investment efficiency of Vietnamese commercial banks. (National University of Economics, Viet Nam, 2002).

[2] Le Dan, Applying statistical methods to analyze the performance of Vietnamese commercial banks (National University of Economics, Viet Nam, 2004).

[3] N. V. Hung, Analysis of factors affecting the performance of Vietnam commercial banks. (National University of Economics, Vietnam, 2008).

[4] N. D. Thanh, J. of Applied Finance \& Banking 2 (2), 289 (2012).
[5] D. V. Dung, The theory of competitive structure of industry with the enhancement of competitiveness of Vietnamese commercial banks today (National University of Economics, Viet Nam, 2015).

[6] Miller, Noulas, Journal of Banking \& Finance, 20 (3), 495509 (1996).

[7] M. Ismail, Study of efficiency and competitive behaviour of commercial banks in Malaysia (Cardiff Business School, University of Wales, Cardiff, 2005).

[8] B. Casu, C. Girardone, The Manchester School 74 (4), 441 (2006).

[9] K. Mlambo, M. Ncube, African Development Review 23 (1), 4 (2011).

[10] E. Gardener, P. Molyneux, H. Nguyen-Linh, The Service Industries J. 31 (16), 2693 (2011).

[11] R. Arrawatia, A. Misra, V. Dawar, Intern. J. of Law and Management 57 (3), 217 (2015).

[12] W. P. Wong, Q. Deng, Benchmarking: An International Journal 23 (7), 1798 (2016).

[13] N. Apergis, M. L. Polemis, Applied Economics 48, 5276 (2016).

[14] S. G. Castellanos, G. A. Del Ángel, J. G. Garza-García, Competition and Efficiency in the Mexican Banking Industry Theory and Empirical Avidence (Palgrave Macmilan, London, 2016)

[15] M. Z. Abd. Karim, ASEAN Economic Bulletin 8 (3), 289 (2001).

[16] Xiaoqing $\mathrm{Fu}$, Efficiency and competition in china's banking sector. (Cass Business School, City University, London, 2004).

[17] D. Aigner, C. A. Lovell, P. Schmidt, Journal of Econometrics 6, 21-37 (1977).

[18] Meeusen, J. V. D. Broeck, International Economic Review, 18 (2), 435-444 (1977).

[19] Battese G. E, Agricultural Economics, 7, 185-208 (1992).

[20] Battese \& Coelli. Department of Econometrics University of New England Armidale (NSW 2351 Australia 1991). 